information can be obtained from the Secretary, Department of Physics, University College, Gower Street, London, W.C.1.

\section{Society for General Microbiology: Annual Meeting}

THE twentieth general meeting of the Society will be held in the Royal Institution, Albemarle Street, London, W.1, during April 18-20. The sessions on April 18 will be occupied by the presentation of original papers, and in the evening the second Marjory Stephenson Memorial Lecture will be given by Prof. C. B. Van Niel, of the Hopkins Marine Biological Station, Pacific Grove, California, on "Natural Selection in the Microbial World". On April 19 and 20 there will be a symposium on "Mechanisms of Microbial Pathogenicity". The principal contributions have been collected and will be published as a book which will be made available before the meeting (members of the Society, 15s.; others, 25s.). At the meeting the published papers will be taken as read and the two days devoted mainly to discussions following short summaries or commentaries on the published material by the authors concerned. Applications for the book must reach the General Office of the Society, c/o Institute of Biology, Tavistock House, Tavistock Square South, London, W.C.1, by March 15.

\section{University of Sheffield}

THE Department of Fuel Technology of the University of Sheffield, which has been traditionally connected with the properties and combustion of coal and coke, has for some time extended the training of its undergraduates to equip them for careers in chemical engineering as well as fuel. It has become increasingly difficult to separate fuel technology from chemical engineering, and there is a very great demand from all types of industry for chemical engineers. In recognition of this trend, the Department has changed its name to the Department of Fuel Technology and Chemical Engineering and will train students for careers in the fuel-supplying and fuel-using industries, such as the steel industry, plant designing, and oil-chemical and coal-chemical, heavy and light chemical industries.

The following appointments have been made in the University : Mr. R. W. Douglas, at present a member of the Research Laboratories of the General Electric Co., Ltd., to the chair of glass technology in succession to Prof. H. Moore, who is retiring; Dr. G. K. T. Conn, senior lecturer, to be reader in physics; Dr. Gilbert Forbes, senior lecturer, to be reader in forensic medicine; D. Hardwick, to the C. H. Desch research fellowship in metallurgy; and Dr. N. M. Waldron, to the research fellowship in chemistry offered by the Birmingham Chemical Co., Ltd.

\section{Announcements}

Her Majesty Queen Elizabeth the Queen Mother has been elected Chancellor of the University of London in succession to the Right Hon. the Earl of Athlone.

The Physical Society has made the following awards for 1955: Charles Chree Medal and Prize, Dr. D. F. Martyn, chief scientific officer of the Radio Research Board, Commonwealth Scientific and Industrial Research Organization, Australia; Duddell Medal, Dr. R. Kompfner, of the Bell Telephone Laboratories, Inc.; Charles Vernon Boys Prize, Dr. J. W. Mitchell, reader in experimental physics in the University of Bristol.
Dr. J. H. Watson has been appointed chemist and assayer of the Royal Mint in succession to Mr. W. A. C. Newman, who has retired.

Dr. Rhodes W. FaIrbridge, lecturer in geology in the University of Western Australia, has been appointed professor of geology in Columbia University, in succession to Prof. A. K. Lobeck, who has retired.

ThRee Ramsay Memorial Fellowships, normally tenable for two years and worth $£ 450$ a year plus a grant for expenses of research not exceeding $£ 100$ a year, are being offered for chemical research. One of the Fellowships will be limited to candidates educated in Glasgow. Further information can be obtained from the Joint Honorary Secretaries, Ramsay Memorial Fellowships Trust, University College, Gower Street, London, W.C.1, to whom application forms must be sent not later than April 21.

Two scholarships, tenable at research institutions in France during the academic year 1955-56, are being offered to British workers in medical science, excluding clinical medicine, by the Medical Research Council on behalf of the Centre National de la Recherche Scientifique. They are intended for young British graduates in medicine or science who have already had some experience in a branch of medical science, and are worth 50,000-70,000 francs a month, with a supplementary allowance, payable in sterling, for married men. A working knowledge of French is essential. Application forms, to be returned by March 31, and further details can be obtained from the Secretary, Medical Research Council, 38 Old Queen Street, London, S.W.1.

THE Royal Dutch-Shell Group of Oil Companies is offering two research studentships in geophysics, of value $£ 450$ a year ( $\$ 500$ for married men) and tenable for two to three years at the University of Cambridge, which are open to men of any nationality less than twenty-seven years of age on October 1. Further information can be obtained from Mr. B. C. Browne, Department of Geodesy and Geophysics, Downing Place, Cambridge, to whom application forms must be sent not later than June 1.

A Symposium on Intermetallic Semi-conductors will be held at the Services Electronics Research Laboratory, Baldock, Herts, during April 26-27. Further information can be obtained from I. M. Ross at the Laboratory.

THE seventh of the international symposia on crop protection that are held in Ghent each year will take place on April 26, and will coincide with the quinquennial Floralias of Ghent. Those wishing to read a paper must submit it before March 10. Further information can be obtained from the president of the organizing committee, Prof. J. van den Brande, State Agricultural College, Coupure Links 233, Ghent.

THe sixth Students Biological Conference will be held in the Biology Departments of the University of Birmingham during March 27-April 1. Undergraduate and postgraduate students are invited to read papers (not necessarily the outcome of original research work) and reviews; to exhibit collections; and to present demonstrations of field and laboratory work and techniques, etc. The programme will include a conversazione and visits to places of biological and general interest. Further information can be obtained from the Conference Secretary, Botany Department, University, Birmingham 15. 